\title{
The determinants and purpose of income diversification of rural households in Bangladesh
}

\section{Rehan, Feroze}

2019

Rehan , F , Sumelius , J \& Bäckman , S T 2019 , ' The determinants and purpose of income diversification of rural households in Bangladesh ' , International Journal of Agricultural

Resources, Governance and Ecology , vol. 15 , no. 3 , pp. 232-251 . https://doi.org/10.1504/IJARGE.2019.103311

http://hdl.handle.net/10138/320588

https://doi.org/10.1504/IJARGE.2019.103311

acceptedVersion

Downloaded from Helda, University of Helsinki institutional repository.

This is an electronic reprint of the original article.

This reprint may differ from the original in pagination and typographic detail.

Please cite the original version. 


\title{
The determinants and purpose of income diversification of rural households in
}

\section{Bangladesh}

\begin{abstract}
This study determines the factors that affect the nature and extent of household income diversification in Bangladesh. The study also investigates whether the motivation for diversification was to support asset accumulation or survival. The findings show that the extent of the diversification index is determined by household endowments of assets such as wealth, a higher number of earners, higher education, easy access to market, and better infrastructure. The motive for overall diversification was accumulation, not survival. An interesting finding was that off-farm income diversification serves a two-fold purpose. Wealthier households are attracted into offfarm self-employment to get a higher return facilitated by easy access to financial assets, and labour endowment. Credit constrained poor households are influenced by endowment in the form of education and labour to diversify into off-farm wage activities as a mean of survival. Investment in infrastructure, electrification and education does and will support income diversification in Bangladesh.
\end{abstract}

Keywords: off-farm diversification of income; overall diversification of income; motivation for diversification; factors; Simpson index of diversity; patterns of household income; agricultural household model; income diversification; determinants; purpose; Bangladesh.

\section{$1 \quad$ Introduction}

Although Bangladesh has historically been regarded as an agrarian economy, farming is no longer the sole major earnings source of rural households. Rural inhabitants are adopting an income diversification strategy that encompasses two approaches: i) households are creating a portfolio of diverse income-generating activities both within and external to the farming sector (Carter et al., 2004; Minot et al., 2006; Rønning and Kolvereid, 2006). In this case, diversification is referred to as portfolio diversification of the total income and reflects the involvement of more than one activity. Households with diversified portfolios engage in an increasing number of income-generating activities through diversification into new agricultural ventures, such as cash crops, livestock, and/or implementing outside agricultural activities; ii) 
instead of increasing the number of economic activities, off-farm income diversification represents moving out of pure on-farm activities to off-farm income sources (de Janvry and Sadoulet, 2001; Delgado and Siamwalla, 1997; Joshi et al., 2003; Reardon et al., 1992). In this study, diversification has been examined by considering both of these categories of diversification. An index of total income diversification was used in order to capture the extent of overall diversification by taking into account the full range of economic activities adopted by a household. Off-farm income diversification was investigated through the factors influencing the size of off-farm income from various off-farm sources. The literature suggests that there could be many reasons for implementing diversification, whích could, for example, be a means of coping with changing situations and as a risk minimisation strategy (Alderman and Paxson, 1992; Barrett et al., 2001). Conversely, diversification could be adopted as a strategy to enhance income-generating capabilities and grasp the opportunity to earn higher returns (Barrett et al., 2005; Ellis, 2000). Little published evidence exists on how the motives for and determinants of off-farm income diversification conform to or differ from overall income diversification in Bangladesh.

The goals of the paper were threefold. First, this study analysed the patterns of income diversification in Bangladesh and determined whether the diversity of high-income and wealthier households is greater than that of low-income and less wealthy households. Second, the factors that affect the nature and extent of household income diversification in Bangladesh have been determined. Third, this paper identified the purpose of diversification whether it is asset accumulation or survival.

The available studies on income diversification provide inconclusive evidence about how a household's asset and wealth endowment are related to diversification. Many researchers have mentioned that farms with a relatively higher income and wealth have greater diversity and receive greater benefits from diversification than their less diversified counterparts (Abdulai 
and Crole-Rees, 2001; Block and Webb, 2001; McNamara and Weiss, 2005). While Reardon et al. (1992) revealed that income diversification is associated with higher returns. It is argued that wealthier, asset-endowed households have fewer diversified income sources (Minot et al., 2006; Pope and Prescott, 1980 ). Mishra et al. (2004) reported that large farm households with higher incomes are less diversified. It has been empirically observed that households with poorer natural capital endowments, combined with failures of credit and the insurance market, are likely to turn to diversification (de Janvry and Sadoulet, 2001; Dries et al., 2012). In particular, households with poor asset endowments are risk averse (Joshi et al., 2003), and thus diversify in order to lower the risk at the cost of lower income (Dercon and Krishnan, 1996). The efforts in this study are directed to exploring the connection of household's wealth and income diversification using Bangladesh as a case.

Evidence reveals that a significant proportion of rural households participate in and earn from off-farm sources (Davis et al., 2010; Davis et al., 2014). Increasing the proportion of off-farm income in the total income makes it important to determine the main motive behind diversification. Diversification mostly serves two purposes, although it is still unclear which is the main or dominant purpose. The survival perspective asserts that various entry barriers limiting their options force the asset- and income-constrained poor households to engage involuntarily in less lucrative off-farm activities (Carletto et al., 2007; Reardon et al., 2000). In contrast, the wealth accumulation perspective views that the unconstrained "rich" households are attracted to participate deliberately in more lucrative off-farm activities to obtain higher returns (Reardon et al., 2006). If the main objective is survival rather than wealth accumulation for a low-income household, addressing the factors at the policy level could help to improve the poverty status of rural households. It is crucial to study the overall diversification of income and off-farm diversification simultaneously since off-farm income growth is connected with 
agriculture through investment, production, and consumption, and these activities tend to grow in concert with each other (Davis et al., 2010; Lanjouw and Lanjouw, 2001).

This paper contributes to the existing pool of literature in the following ways: i) The study analysed both aspects of diversification together which is uncommon. Investigating them at the same time enabled to evaluate whether the motive is the same for each or whether any differences exist between them. Furthermore, this research approach allowed to identify the distinguishing determinants that affect the decision to undertake off-farm diversification or overall diversification of the income portfolio. Thus, the study helps to promote income diversification in the developing countries. ii) Understanding the indecisiveness in research over whether households with greater wealth and endowed with more assets diversify more than relatively poorer farm households, this paper attempted to provide empirical evidence regarding the types of household which diversify more and the factors that contribute to a higher level of diversification. iii) In spite of its importance, relatively little attention has been directed to off-farm income as a topic at the policy level (Babatunde and Qaim, 2010; Goodwin and Mishra, 2004). A merit of this study is that it separately identified the determinants of wage earnings and self-employed activities. Such untangling is necessary to analyse off-farm diversification, as the two activities have different characteristics, but this has not always been carried out in earlier research (Abdulai and Delgado, 1999; Woldenhanna and Oskam, 2001).

The rest of the paper is organised as follows. Section 2 provides a literature review. Section 3 describes the data and the methods used in this study. In section 4, the patterns of household income sources are outlined, followed by the data sources and methods. Section 5 presents the theoretical model used, and section 6 consists of the econometric models. The results are discussed in section 7 and the paper ends with conclusions. 


\section{$2 \quad$ Literature review}

The causes of diversification can be broadly grouped into push and pull factors. Households with available resources such as land, labour, or skills are pulled to pursue higher return opportunities to earn more. In contrast, households with limited asset endowments are forced to diversify into activities with low entry barriers and consequently receive low returns (Barrett et al., 2005). Therefore, a household's resource endowments are determining factors in the differentiation of the motive for its diversification. Households undertake an accumulation strategy to utilise complementarities between activities such as crop-livestock integration, or to capitalise opportunities created by superior skills, technologies, or endowments. Households endowed with such assets earn higher incomes and are wealthier than other farm households. On the other hand, diversification can also be used as a survival strategy for other households to minimise risk, cope with shocks, and maintain consumption levels (Barrett et al., 2001).

Rehan et al. (2017) analysed on-farm diversification using Bangladeshi data, in which farms involved in non-rice agricultural production in addition to, or as a direct substitute for, rice cultivation was considered as diversified. Farms that only produced rice, however, were defined as non-diversified farms. The study revealed that farm size, access to credit, the age of the household head, the active participation of women in farming activities, and access to the market affected the adoption of on-farm diversification.

Ellis (2000) pointed out five asset groups that influence a household's nature, extent, and diversification strategy. These assets are categorised as natural (e.g., land), human (e.g., education, the number of household earners), financial or its substitutes (e.g., savings, credit), physical (e.g., roads, market and electrification), and social assets (e.g., connection and network). The proposition that a household's asset bundle influences the motives and determinants of diversification in rural settings has been used to analyse income diversification 
in several studies. The same assumption was chosen for the present study, whereby household assets were applied as variables for income diversification analysis. Abdulai and Crole-Rees (2001) used panel data obtained from Southern Mali to investigate the overall portfolio diversification of household income, reporting that poor households have less diversified income portfolios mainly because of the lack of credit access. The same authors pointed that the wealth of the household and market proximity positively affect participation in diversified portfolio income sources. Dercon and Krishnan (1996) considered the household's location, financial capital, and the skills of its members to determine the differences in income portfolios. Furthermore, Minot et al. (2006) identified that natural resources such as land size and regional differences have significant impacts on diversification observed as multiple income sources adopted by households.

Empirical studies have recognised that off-farm income diversification is also affected by a household's asset base. Escobal (2001) conducted an analysis on rural households in Peru focused on the determinants of off-farm income diversification, finding that access to roads, better education, and credit influenced the level of diversification. Rahut et al. (2014) emphasised that the quantity of land owned by the household, the distance to facilities such as schools and health centres, the number of earners and regional dummies have significant impacts on off-farm diversification. The relationship of household assets and wealth with income defines the motive for diversification. Dimova and Sen (2010) argued that under the survival motive, asset and income poorer households are more likely to diversify than richer households. In this situation, the asset holdings and the wealth of the household are negatively related to the diversification index and income. In contrast, the accumulation motive is associated with wealthier households diversifying more. In this case, the diversification index and income demonstrate a positive relationship with the asset holdings and wealth of the household. 


\section{$3 \quad$ Data and methods}

\subsection{Data sources}

The data used in this study was obtained from a comprehensive survey of farm households in the central, northern, and southwest regions of Bangladesh which was conducted in JuneSeptember 2014. These regions cover both wet and dry agro-ecological zones of Bangladesh. A multi-stage random sampling method was used to select 260 farm households from three regions of the country. The first stage was the purposive selection of the following districts in Bangladesh: two districts (Tangail and Kishoregonj) located in the central region, three districts (Dinajpur, Joypurhat, and Pabna) of the northern region, and two districts (Jessore and Shatkhira) that belong to the southwest region. A total of 10 villages were randomly selected in the second stage. Two villages each were selected from Tangail, Pabna, and Jessore districts and one village each was chosen from Kishoregonj, Joypurhat, Dinajpur, and Shatkhira districts, making a total of 10 villages. Farm households within these 10 villages were selected at random. Out of 260 farm households, 90 household heads from the central region, 90 from the northern region, and 80 from the southwest region were selected for interview. The sample is not random. It does not perfectly represent the whole country. In spite of this weakness, we believe the quality of the sample is representative enough for the purpose. Personal interviews were conducted using questionnaires that covered items such as household characteristics, production, consumption, expenditure, investment, credit, revenue disaggregated by source, and other issues.

\subsection{Methods of analysis}

To analyse the diversity of income sources, household income was divided into eight activity categories: cereals, non-cereals, livestock, poultry, fisheries, self-employment, wage income, and other sources. Crops, livestock, poultry, and fishery products, either sold or consumed by 
the household, were included in the income. The net income was estimated by deducting input costs from the gross value of total production. Self-employment income is the gross income minus related expenses, which mainly comprise microenterprise and commerce. Other sources comprise off-farm income activities that do not fall into the abovementioned list in the measurement of income. Income received either in cash or in kind was taken into consideration. Household incomes earned in the previous 12 months were assessed for calculation.

In the study, on-farm income consisted of earnings from the production of primary agricultural products such as crops, fish, livestock, and poultry on the farm managed by the households. All other sources of earnings were considered as components of off-farm income. Similarly, Haggblade et al. (2007) pointed out that off-farm income inter alia includes wage income from agriculture earned from working on farms owned by other persons, along with income earned from non-farm activities such as the owner's non-farm enterprises. Davis et al. (2010) have taken a similar approach in their research. In the study, the wealth status of the household was measured from valuable assets in the household's possession, such as livestock, farm equipment, radios, bicycles, and others.

\subsection{Indicators of diversification}

Overall diversification can be measured through various indices which include two factors such as evenness and richness (Patil and Taillie, 1982). Among the large number of indices, the Shannon-Weaver and Simpson indices have been the most widely accepted measures of diversity (Gorelick, 2006). However, Routledge (1979) prefers Simpson's index over the Shannon index, concluding that Simpson is the best single measure of diversity. Furthermore, Magurran (1988) identified that the Simpson index is less sensitive to sample size and to the degree of richness compared to the Shannon index. Rather, it is more sensitive to the degree of evenness than the Shannon index. Thus, Simpson's index of diversity (SID) has been used to 
measure farm, income or agricultural diversity in a number of studies (see Ibrahim et al., 2009; Jones et al., 2014; Joshi et al., 2003; Minot et al., 2006). In view of this, Simpson's index of diversity appeared to be an appropriate choice for this study to measure the overall diversification of the income portfolio, which is defined as:

$S I D=1-\sum_{i} P_{i}^{2}$

where $\mathrm{P}_{\mathrm{i}}$ is the proportion of income derived from source $i$. SID considers both richness (the number of income sources) and evenness (the distribution of income between different sources). The index is created by calculating each source of income weighted by its contribution to the total income. The value of SID falls between ' 0 ' and ' 1 '.

Off-farm diversification however, measured by the income earned from off-farm activities such as self-employment and wage earnings, determines the movement to activities other than pure cultivation.

\section{$4 \quad$ Patterns of household income}

Off-farm income as a whole was found to comprise almost one-third of the total household income. Figure 1 presents the percentages of the proportion of household income generated from various farm and off-farm activities. On average, farm income contributes 69 percent of the total household income, the remaining 31 percent coming from off-farm activities. Income from cereal and non-cereal crops accounts for 21 percent and 37 percent of the total earnings respectively. This is followed by the income share from self-employment (15 percent) and wages (11 percent).

The data were first grouped in income tertiles based on the total income of the households. The percentages of households in tertile I, tertile II and tertile III were $33.46 \%, 33.46 \%$ and $33.07 \%$ respectively. Low-earning households (tertile I) depend more on off-farm income than higher 
income families. The wage income, however, contributes a greater proportion of their off-farm income than earnings from self-employment. The connection can be observed after analysing the data according to income group classifications. In Figure 1, the data are grouped according to income tertiles based on the total net income of the households. This reveals that the highest tertile (III) has the lowest proportion of income generated from off-farm income sources. The lowest (I) and middle-income (II) groups earn more than 40 percent of their total income from off-farm activities. On the other hand, this proportion deceases to 24 percent in the highest

Figure 1 Percentages of household earnings from different sources according to the total income tertile

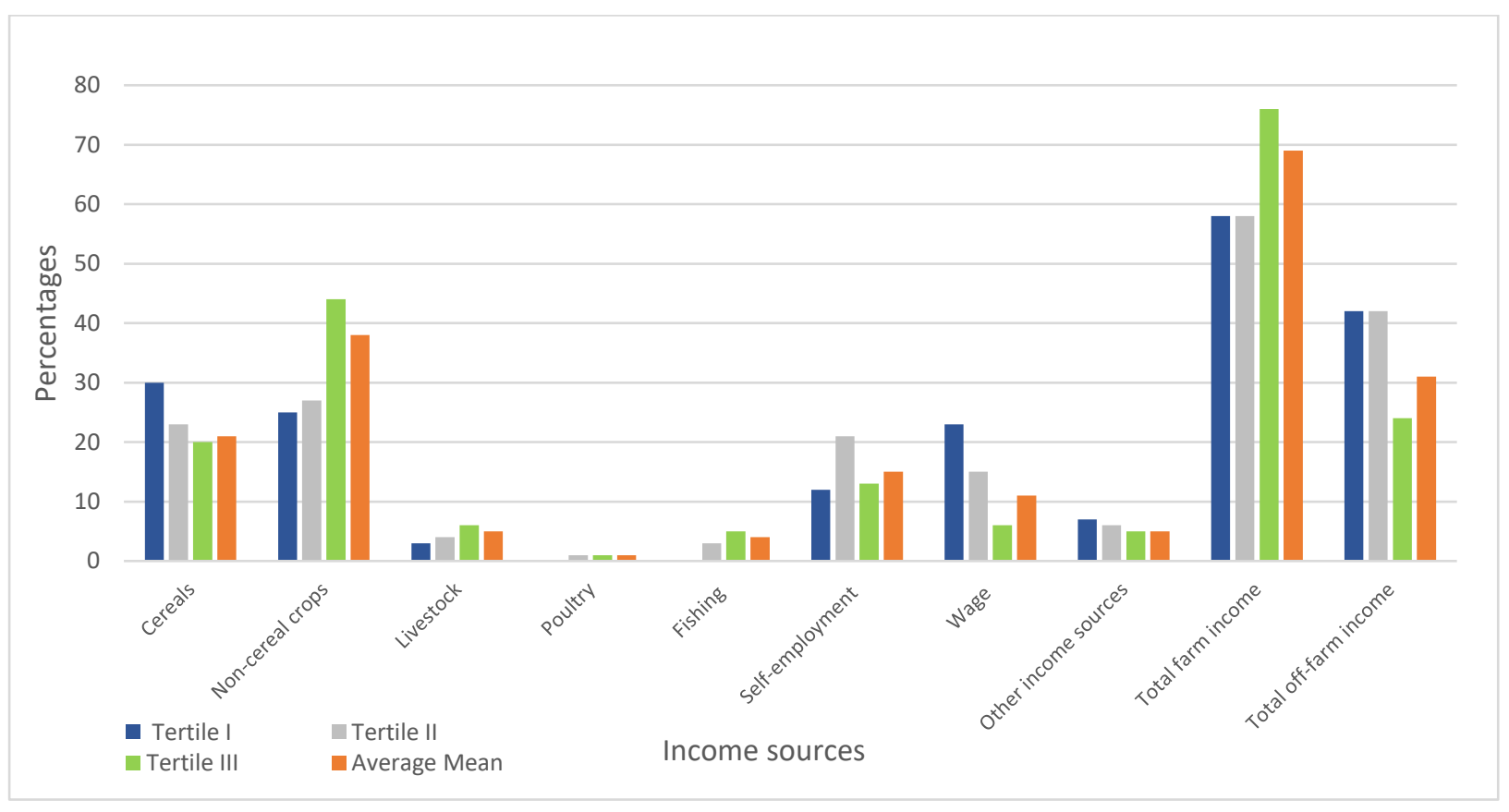

Source: Authors

income earnings across the tertiles in order to ascertain their role in the household income structure. This disaggregation demonstrated that the proportion of wage earning falls as a function of an increasing income level. Higher income households earn 6 percent of their total household income from wages, whereas the corresponding proportion for the poorest (lowest tertile) households amounts to 23 percent of the total income. In comparison, the ratio of 
earnings from self-employment activities increases in the middle income (II) group to 21 percent, but then falls in the highest income group (tertile III), indicating that wage income is more important than self-employment earnings for a low-income (tertile I) household.

Table 1 Levels of household income according to the total income tertile in Bangladeshi taka (BDT)

\begin{tabular}{|c|c|c|c|c|}
\hline Income sources & Tertile I & Tertile II & Tertile III & Average Mean \\
\hline Cereals & 26,025 & 47,590 & 89,923 & 54,377 \\
\hline Non-cereal crops & 21,297 & 58,793 & 207,445 & 95,416 \\
\hline Livestock & 2,256 & 9,022 & 29,393 & 13,496 \\
\hline Poultry & 78 & 2,138 & 5,615 & 2,599 \\
\hline Fishing & 810 & 6,764 & 24,076 & 10,498 \\
\hline Self-employment & 10,025 & 45,331 & 63,544 & 39,541 \\
\hline Wage & 19,254 & 32,565 & 30,965 & 27,581 \\
\hline Other income sources & 5,816 & 12,057 & 21,069 & 12,950 \\
\hline Total farm income & 50,468 & 124,309 & 356,454 & 176,387 \\
\hline Total off-farm income & 35,095 & 89,954 & 115,579 & 80,073 \\
\hline Total income & 85,563 & 214,263 & 472,033 & 256,461 \\
\hline
\end{tabular}

Source: Authors 
As seen in Table 1, there are some differences regarding the levels of household income among the three tertiles. The total mean income of the high-income group (tertile III) is more than five times that of the lowest income group (tertile I) and more than twice that of the middle-income group (tertile II). While the highest income group (tertile III) receives the highest returns from non-cereal crop cultivation, the lowest income group (tertile I) obtained the largest income from cereal farming, which was followed by wage income. The mean wage income was higher in the middle-income group (tertile II), but then lower again in the highest income group (tertile III). However, self-employment activities provided 6-fold and 4.5-fold more income in the highest and middle-income groups respectively, compared to that of the lowest income group (tertile I).

Table 2 reveals that among income sources, the rate of participation was highest in crop cultivation. However, 39 percent and 38 percent of households took part in wage income and self-employment activities respectively. The findings indicate that the proportion of

Table 2 Participation in income activities according to the total income tertile

\begin{tabular}{lllll}
\hline Income sources & Tertile I & Tertile II & TertileIII & Average \\
& $(\%)$ & $(\%)$ & $(\%)$ & Mean $(\%)$ \\
\hline Cereals & 74.00 & 86.00 & 87.00 & 82.00 \\
Non-cereal crops & 93.00 & 95.00 & 98.00 & 95.00 \\
Livestock & 13.00 & 28.00 & 53.00 & 31.00 \\
Poultry & 1.00 & 8.00 & 7.00 & 6.00 \\
Fishing & & & & \\
Self-employment & 5.00 & 15.00 & 27.00 & 16.00 \\
& 23.00 & 47.00 & 47.00 & 39.00
\end{tabular}




$\begin{array}{lcccc}\text { Wage } & 47.00 & 39.00 & 29.00 & 38.00 \\ \text { Other income sources } & 11.00 & 15.00 & 16.00 & 14.00 \\ \text { Total farm income } & 98.00 & 100.00 & 100.00 & 99.00 \\ \text { Total off-farm income } & 69.00 & 79.00 & 69.00 & 72.00\end{array}$

householders who earn a wage income declines as a function of increasing household income, being 29 percent in the high-income group, 39 percent in the middle group, and 47 percent in the lowest income group. In contrast, involvement in self-employment rises with the income level. Thus, wage and self-employment activities clearly show a different pattern depending on the household income level.

The magnitude of Simpson's total income diversification index across the income tertiles and wealth tertiles is presented in Figure 2 and 3. Diversification increases with income, and the highest income group (tertile III) is more diversified than the others.

Figure 2 Total income diversification index of according to income tertile

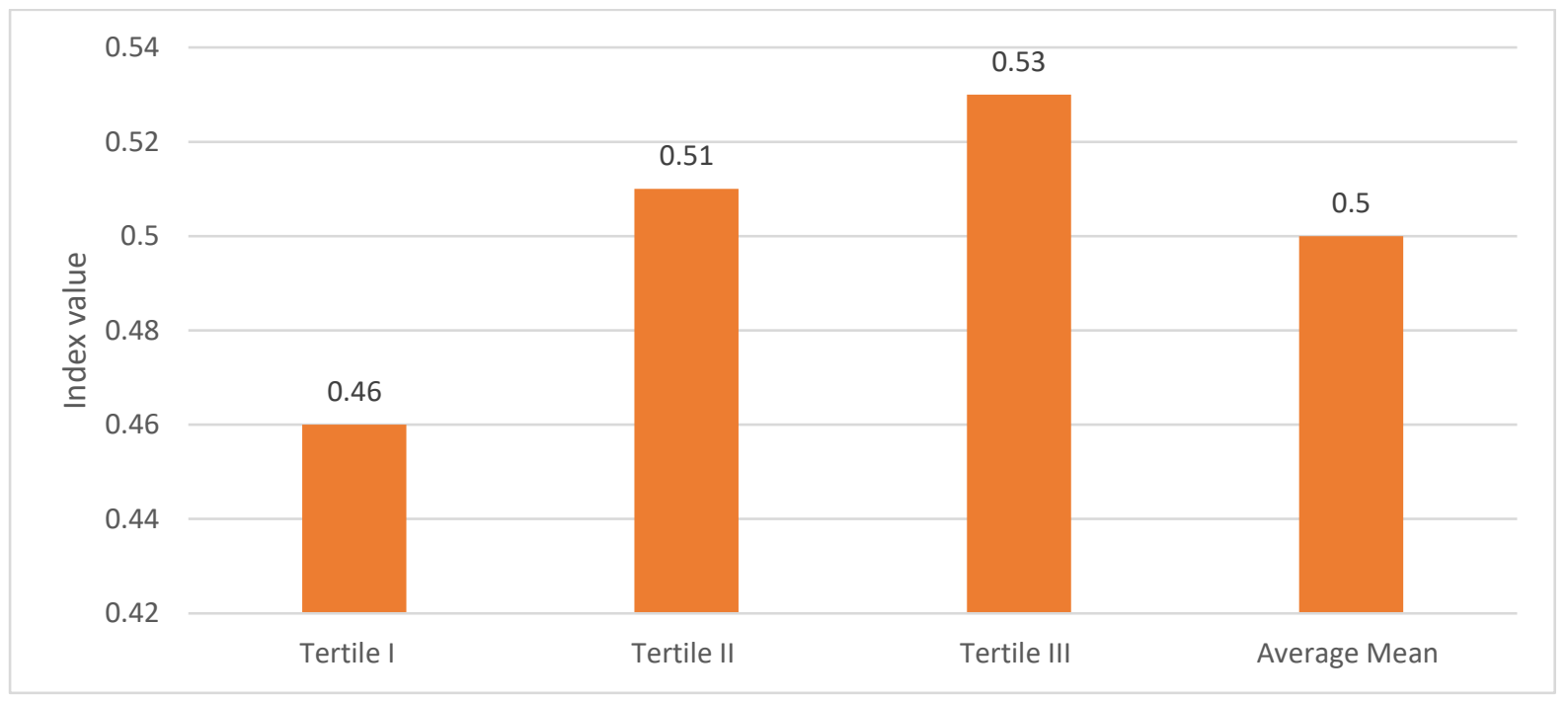


Similarly, overall diversification increases with wealth, and the wealthiest group (tertile III) is more diversified than the others. In addition, Figure 2 shows that the average income of the wealthiest tertile (tertile III) is more than twice that of the least wealthy tertile (tertile I).

Figure 3 Diversification index of total income and average income according to wealth Tertile

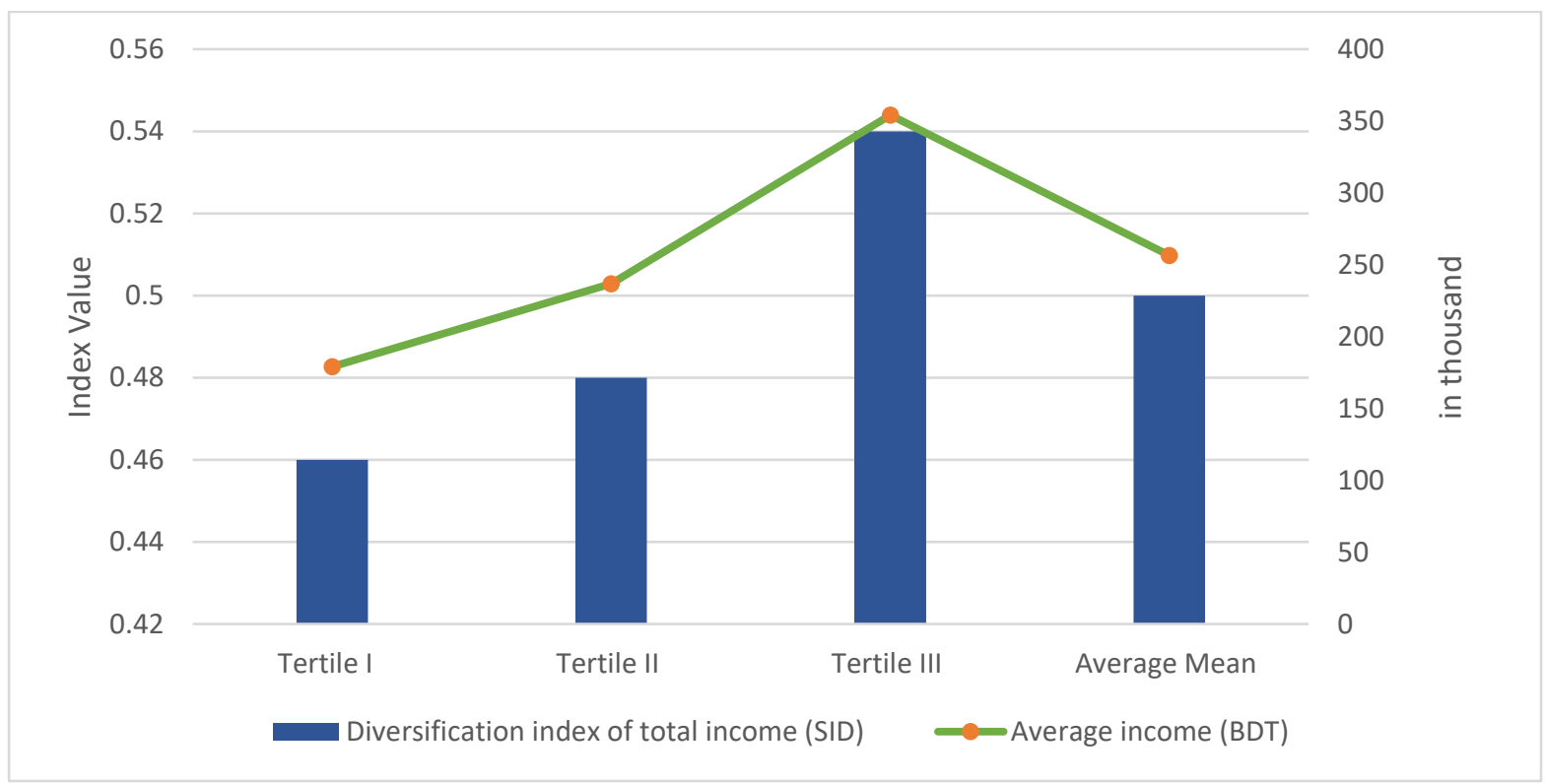

\section{$5 \quad$ Theoretical model}

The agricultural household model (AHM) illustrates that production, consumption, and labour allocation decisions are interlinked. Escobal (2001) followed the rural household models described by Singh et al. (1986) and de Janvry and Sadoulet (2001), reporting that the maximisation of utility by households depends on constraints such as cash constraints, exogenous prices for tradeable items, production technologies related to farm and off-farm activities, and an equilibrium condition for self-sufficiency in farm production and family labour. Labour allocation between farm and off-farm activities can be determined through the first-order conditions of this type of model, which delivers a system of factor supply and demand functions. The following reduced-form equation was used in the present study: 
$S_{i j}=f\left(p ; z_{a g}, z_{o a g}, z_{k}, z_{h}, z_{p u}, z_{g}\right)$,

where $S_{i j}$ represents the net farm and off-farm income proportions for the $i^{\text {th }}$ household, and $p$ is the vector of exogenous input and output prices. The $z$ vectors are the fixed assets available to the household as follows: $z_{a g}$ represents farm assets, $z_{\text {oag }}$ off-farm assets, $z_{k}$ key financial assets, $z_{h}$ human-capital assets, $z_{p u}$ public assets, and $z_{g}$ represents other key assets related to the characteristics of the area.

\section{$6 \quad$ Econometric models}

Two models with two different dependent variables were used in this analysis. First, the study investigated the factors determining household off-farm income levels using Tobit estimation. Second, determinants of diversification of the total household income portfolio based on Tobit estimation are discussed here. The following independent variables were used for the two models:

$X 1=$ Age of the household head in years

$X 2=$ Education of the household head in years

$X 3=$ Number of household earners

$X 4=$ Size of agricultural land

$X 5=$ Access to credit (dummy: yes $=1$, no $=0)$

$X 6=$ Wealth of the household, which is measured by valuable assets or household possessions such as livestock, farm equipment, radios, bicycles, and others.

$X 7=$ Distance to the nearest town in $\mathrm{km}$.

$X 8=$ Northern region dummy (dummy: yes $=1$, otherwise $=0)$

$X 9=$ Central region dummy (dummy: yes $=1$, otherwise $=0$ ). 
Some households do not derive income from certain income sources and rely on only one source for earnings. This results in zero observations in such cases. The Tobit model considers zero observations and offers a more precise estimation (Wooldridge, 2002). In order to minimise the heteroscedasticity bias, a corrective measure such as weighting the heteroscedasticity causing variable, was adopted during estimation of the coefficients. The Tobit model is formulated as follows:

$y^{*}=\beta^{\prime} x+\varepsilon,($ Tobit model censored from below at the value of 0$)$

$y=0$ if $y^{*} \leq 0, y=y^{*}$ otherwise

Here, $y$ measures the income level from off-farm activities for the first model, and SID for the second model, while $\mathrm{x}$ represents the independent variables and $\varepsilon$ denotes the error term. The 'NLOGIT' software package (version 5.0) was used for the data analyses.

\section{$7 \quad$ Results and discussion}

Table 3 shows descriptive statistics for the independent variables, which indicate that the average formal education of the households' head was 5 years. The household averaged nearly 44 years of age and ranged from 22 years to 67 years. On average, the households had 138 decimals of agricultural land. The table also showed that 58 percent of the households

Table 3 Descriptive statistics

\begin{tabular}{lllll}
\hline Variables & Mean & Std. Dev. & Minimum & Maximum \\
\hline Education of the household head (years) & 5.06 & 3.98 & 0.00 & 16.00 \\
Age of the household head (years) & 43.70 & 9.71 & 22.00 & 67.00 \\
Number of household earners (person) & 1.75 & 0.92 & 1.00 & 5.00 \\
Size of agricultural land holding & 138.0 & 105.6 & 2.00 & 580.0 \\
(decimal) & & & & \\
Access to credit (yes $=1$, no $=0)$ & 0.58 & 0.49 & 0.00 & 1.00
\end{tabular}




\begin{tabular}{|c|c|c|c|c|}
\hline Wealth of the household $(10,000$ & 3.74 & 4.41 & 0.30 & 35.00 \\
\hline \multicolumn{5}{|l|}{ Bangladeshi taka (BDT). } \\
\hline Distance to the nearest town $(\mathrm{km})$ & 6.96 & 4.75 & 0.50 & 22.00 \\
\hline $\begin{array}{l}\text { Northern region of Bangladesh (yes }=1 \text {, } \\
\text { otherwise }=0 \text { ) }\end{array}$ & 0.34 & 0.47 & 0.00 & 1.00 \\
\hline $\begin{array}{l}\text { Central region of Bangladesh (yes }=1 \text {, } \\
\text { otherwise }=0 \text { ) }\end{array}$ & 0.34 & 0.47 & 0.00 & 1.00 \\
\hline
\end{tabular}

had access to credit. The average available earning members within a household were 1.75 persons and this varied from 1 to 5 persons. Regarding wealth, each household possessed 37,400 Bangladeshi taka equivalent of valuable assets on average. Approximately $7 \mathrm{~km}$ was the average distance to the nearest town.

\subsection{Determinants of household off-farm income levels}

In this section, the study identifies and analyses the determinants of off-farm income levels. It is of benefit to identify the factors which facilitate households to earn more income from a particular off-farm activity. Table 4 presents the results.

It was found that the wage income level is positively associated with more years in education at the 1 percent level of significance. Education creates an opportunity for wage income through achieving the necessary entry or formal requirements. Increasing the level of education enhances the efficiency and wage rate of the household head. Education equips individuals with the ability to learn and acquire skills to make the work more productive. Castex and Dechter (2014) mentioned that education increases an individual's capacity for success in the wage market. Thus, a higher level of education enhances the household's wage income level. Self-employment is not influenced by an increasing level of education, possibly because the households are engaged in conventional, small-scale activities. Literacy and numeracy alone 
are enough to run micro-enterprises or trades that mainly operate in the local market. The results are consistent with the findings of Corral and Reardon (2001) that education did not have a significant effect on self-employment.

The results confirm that the greater the age of the household head, the lower the income from wages is. Older household heads earn less in wage labour, which also supports the findings reported by de Janvry and Sadoulet (2001). This can be explained through the study of Rupert and Zanella (2015) in which the authors found that hours of work for pay begin to fall as people grew older, which resulted in a decrease in wage earnings, indicating that an older worker prefers to allocate more time to activities other than wage income. Deteriorating health status or job nature of the paid work may stimulate farm households to do so. The heads of households tend to reduce their work load and make life easier for themselves as they grow older, further suggesting that obtaining a wage income is physically demanding and was not attractive to these households.

An increase in the number of earners in the households was found to raise off-farm income from both self-employed enterprises and wage activities. While an additional earning member generates an extra 16,130 BDT (201 USD) of wage income for the household, 10,218 BDT (127 USD) of self-employed income is added to the family income by an additional earning member. More economically active members are able to participate in other income-generating activities than farming. The possible explanation may be the marginal products of labour in farm production decline with a greater labour input. It is worth noting that any individual is motivated to opt for off-farm diversification when the marginal return on labour time in farming drops below the wage rate achievable by that person (Ellis, 2000). The study finds that an increasing number of earning members choose off-farm self-employment and work for pay activities over farming which positively increases household income. 
Greater access to credit sharply increased self-employment earnings in this study. The existence of or access to credit was found to assist households in financing investment and enabled householders to meet the essential business activity expenditures. The paper also found that access to credit had a negative impact on wage income. This finding implies that a household that has access to credit seeks to obtain earnings from self-employment, which tends to reduce the willingness to pursue and engage in less rewarding wage activities. These findings are consistent with those of Berdegue et al. (2001), who suggested that access to credit positively influenced adopting self-employment but not wage earning. The findings signify that a credit facility could be an effective policy intervention in promoting self-employment earnings. Evidence reveals some of the challenges facing entrepreneurs are insufficient loan amounts, collateral requirements and higher interest rates (Hossain, 2004; Mavimbela et al., 2010). Therefore, government and non-government organization (NGO) supported credit should acknowledge an increase in the size of the loan that can meet the needs of the entrepreneurs and financing without collateral at a reasonable cost.

The study also showed that income from self-employment is positively and significantly influenced by wealth. Personal wealth enabled the contribution to initial capital and other necessary facilities such as training, licence fees, and rental payments, all of which are required for self-employment. Wealthier households experience a 'safety net' or security guarantee while entering into a new undertaking compared to their less wealthy counterparts. Therefore, this finding implies that poor households earned more from wage activities than wealthier households. Similarly, Woldenhanna and Oskam (2001) reported that an increase in wealth reduces the level of off-farm wage income. The results suggest that farm households were involved in wage activities because of push factors such as the lack of access to credit and wealth. 


\begin{tabular}{|c|c|c|c|c|}
\hline \multirow[b]{3}{*}{ Variables } & \multicolumn{2}{|c|}{ Tobit estimation } & \multicolumn{2}{|c|}{$\begin{array}{c}\text { Marginal effects after Tobit } \\
\text { estimation }\end{array}$} \\
\hline & Wage income & $\begin{array}{l}\text { Self- } \\
\text { employment } \\
\text { income }\end{array}$ & Wage income & $\begin{array}{l}\text { Self- } \\
\text { employment } \\
\text { income }\end{array}$ \\
\hline & Coefficients & Coefficients & Partial Effect & Partial Effect \\
\hline Education of the & $7376.28 * * *$ & 1574.60 & $3148.07 * * *$ & 666.67 \\
\hline household head & (1695.19) & $(2465.62)$ & $(723.16)$ & $(1041.73)$ \\
\hline Age of the household & $-1889.32 * *$ & -1084.36 & $-806.33^{* *}$ & -459.11 \\
\hline head & $(759.83)$ & $(1102.56)$ & $(322.23)$ & $(465.05)$ \\
\hline Number of household & $37795.50 * * *$ & $24134.60 * *$ & $16130.50 * * *$ & $10218.40 * *$ \\
\hline earners & (7122.66) & (10307.57) & $(3034.30)$ & $(4328.45)$ \\
\hline Size of agricultural land & 64.13 & $-164.52 *$ & 27.37 & $-69.66^{*}$ \\
\hline holding & $(63.84)$ & $(93.40)$ & $(27.21)$ & (39.34) \\
\hline \multirow[t]{2}{*}{ Access to credit } & $-23647.20^{*}$ & $66444.70 * * *$ & $-10092.20^{*}$ & $28132.00 * * *$ \\
\hline & (13450.68) & (20376.09) & $(5741.61)$ & $(8548.37)$ \\
\hline \multirow[t]{2}{*}{ Wealth of the household } & $-4301.09 * *$ & $4390.16^{*}$ & $-1835.63^{* *}$ & $1858.75^{*}$ \\
\hline & $(1985.02)$ & $(2303.22)$ & $(838.18)$ & $(974.49)$ \\
\hline Distance to the nearest & $-4203.02 * * *$ & -2113.10 & $-1793.77 * * *$ & -894.66 \\
\hline town & $(1555.27)$ & $(2081.72)$ & $(659.01)$ & $(880.63)$ \\
\hline Northern region of & -9859.27 & $67020.30 * * *$ & -4207.76 & $28375.70 * * *$ \\
\hline Bangladesh & $(17666.53)$ & $(25450.57)$ & $(7527.81)$ & (10726.16) \\
\hline Central region of & 2727.65 & 16955.50 & 1164.11 & 7178.78 \\
\hline Bangladesh & (17093.60) & (25665.07) & $(7294.62)$ & (10868.42) \\
\hline
\end{tabular}


$\begin{array}{lll}\text { Constant } & 1450.95 & -84890.80\end{array}$

$(36303.72) \quad(55201.74)$

$\begin{array}{lll}\text { Sigma } & 88889.40 * * * & 129404 * * *\end{array}$

Log likelihood function $\quad-1503.67 \quad-1536.25$

Note: $* * *, * *$, and $*$ denote significance at the $1 \%, 5 \%$, and $10 \%$ levels. Standard errors in parentheses.

A larger area of agricultural land was found to lessen the earnings from off-farm selfemployment work, possibly because self-employment is regarded as a substitute for farming. This result is in line with that found in the study by Lanjouw et al. (2001), who reported that a larger land area is a driving force for participation in agricultural income and reduces the reliance on self-employment. The distance to the nearest town strongly affected off-farm wage income. The results demonstrated that, ceteris paribus, a 1-km incremental increase in this distance reduces income from off-farm wage earnings by 1794.00 BDT (22 USD) at the 1 percent level of significance. This is related to income opportunities being more accessible in areas closer to towns than in more distant locations. Moreover, an area closer to the town offers quick and easy movement to the work place with less commuting cost, if any, than in a remote area. Thus, households living nearer to the town were motivated to earn higher income from wage employment.

Finally, there is a significant difference in household earnings from business activities between the northern region and the southwest region (the reference region), since location plays a role in participation in income activities. Households in the northern region earn more of their income from self-employment activities than those in the southwest region. Higher selfemployment income is a result of electrification and better roads, both factors which allow the extension of working hours and reduction of costs in the region. Developed infrastructure 
facilitated a decrease in transaction cost and availability of low-priced alternative supplies, thus escalating self-employment income level in the region.

In brief, the factors that positively influence wage income diversification found in this study are the following: education of the household head, the number of household earners, a younger age of the household head, and a shorter distance to the nearest town. Self-employment was encouraged by the number of household earners, a younger head of the household, access to credit, the wealth of the household, and better infrastructure and electrification. The study also found that some factors differentiate the determining factors of off-farm diversification. The lack of access to financial assets created a barrier to entering into self-employment activities. On the other hand, education was found to be an important factor for wage income diversification.

\subsection{Determinants of the total income diversification index}

This section investigates the total household income diversification index with respect to an income portfolio consisting of multiple income sources from within and/or outside of farming activities measured by SID. The results show that human capital-related variables (education and age of the household head, number of household earners), an infrastructure-related variable (distance to town), financial assets (wealth of the household), and location variables (regional dummy variables) influenced the adoption of an overall portfolio of income diversification (Table 5).

Education was found to be positively and significantly related to income diversification. The income of the more highly educated households was likely to be derived from more sources and was more evenly distributed among these sources. This suggests that education facilitates entry into various activities. It facilitates shifting across multiple endeavours, encourages 
Table 5 Determinants of the total income diversification index

\begin{tabular}{|c|c|c|}
\hline \multirow[b]{4}{*}{ Variables } & Tobit estimation & $\begin{array}{l}\text { Marginal effects } \\
\text { after Tobit } \\
\text { estimation }\end{array}$ \\
\hline & Income & Income \\
\hline & Diversification & Diversification \\
\hline & Coefficients & Partial Effect \\
\hline \multirow[t]{2}{*}{ Education of the household head } & $0.007 * * *$ & $0.007 * * *$ \\
\hline & $(0.002)$ & $(0.002)$ \\
\hline \multirow[t]{2}{*}{ Age of the household head } & $-0.004 * * *$ & $-0.004 * * *$ \\
\hline & $(0.001)$ & $(0.001)$ \\
\hline \multirow[t]{2}{*}{ Number of household earners } & $0.040 * * *$ & $0.040 * * *$ \\
\hline & $(0.010)$ & $(0.010)$ \\
\hline \multirow[t]{2}{*}{ Size of agricultural land holding } & 0.001 & 0.001 \\
\hline & $(0.00)$ & $(0.00)$ \\
\hline \multirow[t]{2}{*}{ Access to credit } & 0.002 & 0.002 \\
\hline & $(0.019)$ & $(0.019)$ \\
\hline \multirow[t]{2}{*}{ Wealth of the household } & $0.010 * * *$ & $0.010 * * *$ \\
\hline & $(0.002)$ & $(0.002)$ \\
\hline \multirow[t]{2}{*}{ Distance to the nearest town } & $-0.005^{* * *}$ & $-0.005 * * *$ \\
\hline & $(0.002)$ & $(0.002)$ \\
\hline \multirow[t]{2}{*}{ Northern region of Bangladesh } & $0.073 * * *$ & $0.073 * * *$ \\
\hline & $(0.025)$ & $(0.025)$ \\
\hline Central region of Bangladesh & $0.083 * * *$ & $0.083 * * *$ \\
\hline
\end{tabular}


Constant

Sigma

Log likelihood function
$0.482 * * *$

$(0.053)$

$0.148 * * *$

118.75

Note: Standard errors in parentheses. $* * *, * *$, and $*$ denote significance at the $1 \%, 5 \%$, and $10 \%$ levels.

people to engage in unfamiliar activities. More highly educated farmers diversify more, possibly because they have greater access to information and knowledge than their less educated counterparts. Educated farmers are also likely to be wealthier, which makes them less vulnerable to risk. This factor may facilitate the decision to diversify into producing crops other than staples.

The diversification index values indicate that younger heads of households tend to generate income from more diverse sources. A recent study by UNCTAD (2015) argued that young people have greater enthusiasm to opt for various activities that may be perceived as being risky. The study findings are in line with this study and suggest that people intend to move into a specialisation as they gain more experience over time. Farmers were less likely to spread their earning sources or try any new source of income as they grew older.

This paper also found that a household with one extra earning member was more likely to increase diversification by 4 percent at the 1 percent level of significance, keeping other factors constant. This implies that a household will possess a range of skills if it has a large number of earners in the family. Such a situation is a motivating and enabling factor for the diversification of income sources, although the members will have individual specialisations. The household's wealth also positively increased the likelihood of diversification. A possible explanation is that 
profit earned from one activity can be invested in another, which has the effect of relaxing financial constraints. Ellis (2000) argued that households invest in diversification to increase their income-generating capabilities. Personal wealth allows wealthier households to respond more quickly to lucrative opportunities (Reardon et al., 2006). Since the results indicate that wealthier households intentionally undertake a wider range of activities with the expectation of better returns, this study can conclude that diversification into multiple activities is more an accumulation strategy than a survival strategy. Abdulai and Crole-Rees (2001) reached a similar conclusion when they stated that wealthier households are more diversified than poorer households.

The results of this paper demonstrate that the closer a household is to the local town, the more this is associated with diversification. Such proximity provides more opportunities for multiple income-generating activities, both on and off the farm. A relatively short distance to a town market enables nearby farms to sell various fresh agricultural products at the best price. Items such as vegetables, fruit, and dairy products are perishable and must be sold quickly in the markets. Therefore, quick and easy access to a market provides an opportunity for farmers to diversify, a result consistent with that reported by Schwarze and Zeller (2005). The location of the region is also vital. The regional variables indicate that farm households in the northern and central regions were likely to be more diversified than those in the southwest region (the reference region). Petit and Barghouti (1992) pointed out that agro-climatic factors influence regional diversification. The agro-climatic conditions in the northern and central regions of Bangladesh may thus be more favorable for diversification than the southwest region. Better infrastructure and electrification also play important roles by providing opportunities for the adoption of multiple activities. 


\section{Conclusion and policy considerations}

The study analysed and specified the purposes associated with the decision of rural households to adopt diversification considering all the approaches which is scarce in existing literatures. Thus, one of the key findings from this paper is that purposes of income diversification are different and depend on the nature of diversification. The purpose of the overall diversification was the accumulation of wealth, but the motive for off-farm diversification depended on the type of off-farm activities. Credit-constrained poor households were pushed into off-farm wage activities as a means of survival, while wealthier households were pulled into self-employment diversification to enable growth in wealth, in line with overall portfolio diversification. Poor households diversified mainly through off-farm wage activities, which were stimulated by being endowed with labour and a higher level of education. The results suggest that policy needs to emphasise measures such as easier access to financial services and educational development programs in order to offer better lives to poor households through off-farm diversification.

The aim of this study was also to identify the households which diversify more than others. The findings showed that the wealthier households adopt diversification more than the poorer farm households. Richer households escalate the magnitude of diversification with the prospect of acquiring affluence. Their wealth eases financial constraints and allows them to invest in a wider range of lucrative activities. Thus, the results specified that overall diversification primarily should be viewed as a strategic choice of richer farm households to accumulate wealth over the survival motive of poorer households, which is a noteworthy finding from this paper.

Finally, this study recognized the distinguishing factors that lead some households to diversify more than others. The results indicate that a higher level of diversification is related to 
household income and asset holdings such as wealth, a greater number of earners, and the level of education. Educated farmers diversify more than their less educated counterparts. In addition, easy access to the market and better infrastructure facilitated overall diversification. Wealth appears to be a dominant factor explaining the perspective of diversification. Wealthier households with the prospect of expanding wealth and the benefit of easy investment opportunities in multiple activities deliberately opt for diversification. This paper also found that younger farmers participate more in off-farm wage activities and diversify their total income more than older farmers.

It is worth mentioning that, since off-farm income growth and diversification are connected to agriculture, agriculture plays a significant role in diversification, and policy grounded on the assumption that agriculture is unnecessary will hinder development. This study suggests, contrary to the broadly held notion that diversification is a syndrome of a declining agricultural sector, that diversification is associated with agriculture.

In order to ensure rural progress, policies should serve both the benefit of wealthier farm households and the development of poor farm households. Specifically, policy leading to granting access to credit, raising the education level, development of infrastructure and electrification will support households in diversifying their income sources in Bangladesh. Policies focused on addressing the characteristics of credit facilities conducive to the entrepreneurs generating more self-employed earnings are crucial. Generally, credit subsidies offered by the government mostly apprehended by the large farms in developing countries. In order to change the situation, these policies should tie the heterogenous households' requirement and offer credit at a reasonable cost by arranging a flexible repayment schedule. The government policy-maker in collaboration with non-government organizations (NGOs) and donor agencies needs to address this combined work. Generating an instrument for 
recognition of real entrepreneurs and developing a system of supervised credit without collateral is advised.

The results of this study emphasise that policies regulated towards enhancing the household education status are important. These policies may include increasing the number of schools in rural areas, tuition-free schooling, a food for education (FFE) program for motivating children to go school at the right age and more investment in education by the way of public-private partnerships (PPPs). Moreover, an awareness program may be initiated in which government, NGOs and the media should act together. The findings also suggest that policy geared towards increased and continuous investment in infrastructure such as roads and electrification is necessary.

Addressing these actions in the policy will support households in diversifying their income sources, which could consequently facilitate households to raise their income-generating opportunities to their benefit and allow poor households to improve their living standards.

\section{References}

Abdulai, A. and Crole-Rees, A. (2001) 'Determinants of income diversification amongst rural households in Southern Mali', Food Policy, Vol. 26, pp. 437-452.

Abdulai, A. and Delgado, C. L. (1999) 'Determinants of nonfarm earnings of farmbased husbands and wives in Northern Ghana' American Journal of Agricultural Economics, Vol. 81, pp. 117-130.

Alderman, H. and Paxson, C.H. (1992) Do the poor insure? A synthesis of the literature on risk and consumption in developing countries, Policy Research Working Paper, No. WPS-1008, Washington, DC, World Bank. Available online at: http://documents.worldbank.org/curated/en/682441468765261969/pdf/multi0page.pdf 
(accessed on 5 May 2019).

Babatunde, R.O. and Qaim, M. (2010) 'Impact of off-farm income on food security and nutrition in Nigeria', Food Policy, Vol. 35, pp. 303-311.

Barrett, C.B., Bezuneh, M, Clay, D.C. and Reardon T. (2005) 'Heterogeneous constraints, incentives and income diversification strategies in rural Africa,' Quarterly Journal of International Agriculture, Vol. 44, No. 1, pp. 37-60.

Barrett, C.B., Reardon, T. and Webb, P. (2001) 'Non-farm income diversification and household livelihood strategies in rural Africa: Concepts, dynamics, and policy implication', Food Policy, Vol. 26, pp. 315-331.

Berdegue, J. A., Ramirez, E., Reardon, T. and Escobar, G. (2001) 'Rural nonfarm employment and incomes in Chile', World Development, Vol. 29, No. 3, pp. 411-425.

Block, S. and Webb, P. (2001) 'The dynamics of livelihood diversification in postfamine Ethiopia', Food Policy, Vol. 26, pp. 333-350.

Carletto, G., Covarrubias, K., Davis, B., Krausova , M., Stamoulis, K., Winters, P. and Zezza, A. (2007) 'Rural income generating activities in developing countries: Reassessing the evidence', Electronic Journal of Agricultural and Development Economics, Vol. 4, No. 1, pp. 146-193. Available online at: http://www.fao.org/3/aai195e.pdf (accessed on 5 May 2019).

Carter, S., Tagg, S. and Dimitratos, P. (2004) 'Beyond portfolio entrepreneurship: Multiple income sources in small firms', Entrepreneurship and Regional Development, Vol. 16, No. 6, pp. 481-499. 
Castex, G. and Dechter, E. K. (2014) 'The changing roles of education and ability in wage determination', Journal of Labor Economics, Vol. 32, No. 4, pp. 685-710.

Corral, L. and Reardon, T. (2001) 'Rural nonfarm incomes in Nicaragua', World Development, Vol. 29, No. 3, pp. 427-442.

Davis, B., Winters, P., Carletto, G., Covarrubias, K., Quinones, E. J., Zezza, A., Stamoulis, K., Azzarri, C. and Digiuseppe, S. (2010) 'A cross-country comparison of rural income generating activities', World Development, Vol. 38, No. 1, pp. 48-63.

Davis, B., Di Giuseppe, S., Zezza, A., (2014) Income diversification patterns in rural Sub-Saharan Africa: Reassessing the evidence, Policy Research Working Paper, No. . WPS-7108, Washington, DC, World Bank Group, pp. 1-36. Available online at: http://documents.worldbank.org/curated/en/861761468340796327/pdf/WPS7108.pdf (accessed on 5 May 2019).

De Janvry, A. and Sadoulet, E. (2001) 'Income strategies among rural households in Mexico: The role of off-farm activities', World Development, Vol. 29, No. 3, pp- 467480.

Delgado, C. and Siamwalla, A. (1997) Rural economy and farm income diversification in developing countries, International Food Policy Research Institute, MSSD

Discussion Paper, No. 20, pp.1-23. Available online at: https://pdfs.semanticscholar.org/00b3/51913259c0b5efbacdd24ab4768779e08da1.pdf (accessed on 5 May 2019).

Dercon, S. and Krishnan, P. (1996) 'Income portfolios in rural Ethiopia and Tanzania: choices and constraints', The Journal of Development Studies, Vol. 32, No. 6, pp. 850875. 
Dimova, R. and Sen, K. (2010) Is household income diversification a means of survival or a means of accumulation? Panel data evidence from Tanzania, Brooks World Poverty Institute Working Paper Series, No. 122, The University of Manchester, Manchester, pp. 1-27. Available online at:

https://pdfs.semanticscholar.org/5613/95e1d9c28efd1d40a593e2f66a2c87cf0600.pdf (accessed on 21May 2019).

Dries, L., Pascucci, S. and Gardebroek, C. (2012) 'Diversification in Italian farm systems: Are farmers using interlinked strategies'? New Medit, Vol. 32, No. 4, pp. 715.

Ellis, F. (2000) 'The determinants of rural livelihood diversification in developing countries', Journal of Agricultural Economics, Vol. 51, No. 2, pp-289-302.

Escobal, J. (2001) 'The determinants of nonfarm income diversification in rural Peru', World Development, Vol. 29, No. 3, pp- 497-508.

Goodwin, B. K. and Mishra, A. K. (2004) 'Farming efficiency and the determinants of multiple job holding by farm operators', American Journal of Agricultural Economics, Vol. 86, No. 3, pp- 722-729.

Gorelick, R. (2006) 'Combining richness and abundance into a single diversity index using matrix analogues of Shannon's and Simpson's indices', Ecography, Vol. 29, pp525-530.

Haggblade, S., Hazell, P. and Reardon, T. (Eds.), (2007) Transforming the Rural Nonfarm Economy: Opportunities and Threats in the Developing World, Johns Hopkins University Press, Baltimore. 
Hossain, M. (2004) Rural non-farm economy in Bangladesh: A view from household surveys, Centre for Policy Dialogue Working Paper, No. 40, Dhaka.

Available online at: http://www.cpd.org.bd/pub_attach/op40.pdf (accessed on 21May 2019).

Ibrahim, H., Rahman, S.A., Envulus, E.E. and Oyewole, S.O. (2009) 'Income and crop diversification among farming households in a rural area of North-central Nigeria', Journal of Tropical Agriculture, Food, Environment and Extension, Vol. 8, No. 2, pp. 84-89.

Jones, A. D., Shrinivas, A. and Bezner-Kerr R. (2014) 'Farm production diversity is associated with greater household dietary diversity in Malawi: Findings from nationality representative data', Food Policy, Vol. 46, pp. 1-12.

Joshi, P. K., Gulati, A., Birthal, P. S. and Tewari, L. (2003) Agriculture diversification in South Asia: Patterns, determinants, and policy implications, International Food Policy Research Institute, MSSD Discussion Paper, No. 57, Washington, DC, pp. 1-51. Available online at: https://www.researchgate.net/publication/244269319 (accessed on 23 May 2019).

Lanjouw, J.O. and Lanjouw, P. (2001) 'The rural non-farm sector: issues and evidence from developing countries', Agricultural Economics, Vol. 26, pp. 1-23.

Lanjouw, P., Quizon, J. and Sparrow, R. (2001) 'Non-agricultural earnings in periurban areas of Tanzania: Evidence from household survey data', Food Policy, Vol. 26, pp. 385-403.

Magurran, A.E. (1988) Ecological Diversity and Its Measurement, Princeton University Press, Princeton. 
Mavimbela, P., Masuku, M. B. and Belete, A. (2010) 'Contribution of savings and credit cooperatives to food crop production in Swaziland: A case study of smallholder farmers', African Journal of Agricultural Research, Vol. 5, No. 21, pp. 2868-2874.

McNamara, K. T. and Weiss, C. (2005) 'Farm household income and on- and off-farm diversification', Journal of Agricultural and Applied Economics, Vol. 37, No.1, pp.3748.

Minot, N., Epprecht, M., Anh, T. T. T. and Trung, L. Q. (2006) Income diversification and poverty in the Northern uplands of Vietnam, International Food Policy Research Institute Research Report, No. 145, Washington, DC. Available online at: http://www.ifpri.org/sites/default/files/publications/rr145.pdf (accessed on 25 May 2019).

Mishra, A.K., El-Osta, H.S. and Sandretto, C.L. (2004) 'Factors affecting farm enterprise diversification', Agricultural Finance Review, Vol. 64, No. 2, pp. $151-166$.

Patil, G. P. and Taillie, C. (1982) 'Diversity as a concept and its measurement', Journal of the American Statistical Association, Vol. 77, No. 379, pp. 548-561.

Petit, M. and Barghouti, S. (1992) Diversification: Challenges and opportunities, in Barghouti, S., Garbus, L., and Umali, D. (Eds): Trends in Agricultural Diversification: Regional Perspectives, World Bank Technical Paper, No. 180. pp. 1-13. Available online at: http://documents.worldbank.org/curated/en/473921468772148804/pdf/multipage.pdf (accessed on 23 May 2019).

Pope, R.D., and Prescott, R. (1980) 'Diversification in relation to farm size and other socioeconomic characteristics', American Journal of Agricultural Economics, Vol. 62, pp. 554-559. 
Rahut, D. B., Ali, A., Kassie, M., Marenya, P. P. and Basnet, C. (2014) 'Rural livelihood diversification strategies in Nepal', Poverty and Public Policy, Vol. 6, No. 3, pp. 259-281.

Reardon, T., Bedegue, J., Barrett, C.B., Stamoulis, K. (2006) 'Household income diversification into rural non-farm activities', in: Haggblade, S., Hazell, P. and Reardon, T., (Eds): Transforming the Rural Non-Farm Economy, Johns Hopkins University Press, Baltimore.

Reardon, T., Delgado, C. and Matlon, P. (1992) 'Determinants and effects of income diversification amongst farm households in Burkina Faso', The Journal of Development Studies, Vol. 28, No. 2, pp. 264-296.

Reardon, T., Taylor, J.E., Stamoulis, K., Lanjouw, P. and Balisacan, A. (2000) 'Effects of non-farm employment on rural income inequality in developing countries: An investment perspective', Journal of Agricultural Economics, Vol. 51, No. 2, pp. 266288.

Rehan, S.F., Sumelius, J. and Bäckman, S. (2017) 'Determinants of on-farm diversification in Bangladesh', International Journal of Agricultural Resources, Governance and Ecology, Vol. 13, No. 3, pp. 294-313.

Ronning, L. and Kolvereid, L. (2006) 'Income diversification in Norwegian farm households: Reassessing pluriactivity', International Small Business Journal, Vol. 24, No.4, pp. 405-420.

Routledge, R. D. (1979) 'Diversity indexes: Which ones are admissible?' Journal of Theoretical Biology, Vol. 76, No. 4, pp. 503-515. 
Rupert, P. and Zanella, G. (2015) 'Revisiting wage, earnings, and hours profiles' Journal of Monetary Economics, Vol. 72, pp. 114-130.

Schwarze, S. and Zeller, M. (2005) 'Income diversification of rural households in Central sulawesi, Indonesia', Quarterly Journal of International Agriculture, Vol. 44, No.1, pp. 61-73.

Singh, I., Squire, L. and Strauss, J. (Eds.), (1986) Agricultural Household Models: Extensions, Applications, and Policy, Johns Hopkins University Press, Baltimore.

UNCTAD (2015) The least developed countries report, United Nations Publication, New York and Geneva. Available online at: https://unctad.org/en/PublicationsLibrary/ldc2015_en.pdf (accessed on 25 May 2019).

Woldenhanna, T. and Oskam, A. (2001) 'Income diversification and entry barriers: Evidence from the Tigray region of Northern Ethiopia', Food Policy, Vol. 26, pp. 351365.

Wooldridge, J. M. (2002) Econometric Analysis of Cross Section and Panel Data, MIT Press, Cambridge. 